\title{
JUURNAL.RU
}

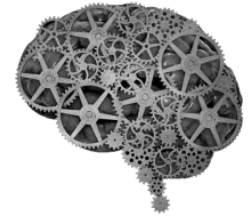

COMPANY GROUP "INTELLEKT"

Логунова А.А. Санкт-Петербургская государственная консерватория им. Н. А. Римского-Корсакова Санкт-Петербург, Россия

doi: 10.18411/lj2016-3-87

\section{«Набукко» Верди: к проблеме большого финала}

В итальянской опере XIX века по крайней мере один из актов завершается действенной массовой сценой, в которой происходит столкновение противоборствующих сил, определяющее дальнейшее течение драмы. Для обозначения такой сцены используется термин «большой финал», близкий и вердиевскому варианту gran finale, и формулировке «расширенный финал» (extended finale) [5], а также «центральный финал» (central finale) и «финалconcertato» $[3,4,6]$. Концентрируя в себе важнейшие сюжетные линии оперы, такие финалы мобилизуют весь арсенал музыкально-драматических средств. Большой финал стал зоной наиболее смелых экспериментов в зрелом творчестве Верди - достаточно вспомнить сцену аутодафе из «Дон Карлоса», сцену триумфального марша из «Аиды» или сцену заседания Совета из «Симона Бокканегры».

Утверждение относительно устойчивой формы большого финала в опере XIX века связывают с творчеством Россини, начиная с оперы «Танкред» (1813) [см.: 5]. Функциональный каркас сцены образуют четыре контрастных раздела. В динамичном первом разделе (tempo d'attacco) музыкальная форма полностью подчиняется драматическому действию, вокальные партии решены в речитативно-ариозной манере. Во втором разделе (pezzo concertato) произошедшие события получают осмысление в медленном ансамбле с хором лирической кульминации финала. Раздел tempo di mezzo несет новый поворот 
сюжета, здесь возвращается подвижный темп, а иногда и материал tempo d’attacco. Завершается финал быстрой стреттой, которая наиболее стабильна по форме, будучи основанной на одной или двух темах с обязательной репризой и кодой. Данная структура получила название «la solita forma» (от итальянского solito - обычный, привычный).

Эксперименты Верди на территории la solita forma начинаются уже на раннем этапе. Так, в «Набукко», открывающем серию вердиевских опер, проникнутых настроениями Рисорджименто, большие финалы концентрируют огромные исполнительские силы и важнейшие сюжетные линии, прежде всего, связанные с патриотической идеей. В четырехактной опере на либретто T. Солеры, завершенной осенью 1841 года и поставленной в La Scala 9 марта 1842 года, Верди дважды обращается к типу финала-concertato — в I и II актах.

Финал I акта открывает марш воинов («тема царской власти» $[1,8])$, сопровождающий прибытие вавилонского царя Набукко в храм Соломона. Напряженный раздел tempo d’attacco с речитативами Набукко и Захарии, иудейского первосвященника, который берет в заложницы дочь царя Фенену, сменяется медленным ансамблем. Примечательно, что именно pezzo concertato здесь становится экспозицией заглавного героя оперы. Ансамбль открывается соло Набукко: его коварные замыслы («Нужно сделать вид, что я уступил, но тем сильнее обрушится мой гнев») облачаются в гибкую кантилену, и только в оркестровом сопровождении напоминает о себе воинственный пунктир. В построении pezzo concertato Верди ярко претворяет идею, к которой он только приближался в опере «Король на час, или Мнимый Станислав» (1840): после развернутого соло ариозно-декламационного склада в других партиях появляются новые мелодические идеи соответственно характерам и конкретным эмоциям. Острый ритм и широкие скачки в партии второй дочери Набукко Абигайль, исполненной мстительных замыслов, отражают ее воинственный темперамент; плавность триольного ритма определяет мелодическую линию Фенены, умоляющей отца сжалиться; с ней в унисон поет иудейский 
военачальник Измаил; решимость и твердость ощущаются в партии Захарии. Вместо более привычной для подобных ансамблей строфической или простой двухчастной формы, Верди, со свойственной ему мелодической щедростью, свободно соединяет ряд родственных тем, завершая композицию развернутой кодой. Tempo di mezzo несет очередной острый поворот - в ответ на заносчивые речи Набукко, Захария угрожает кинжалом Фенене, но Измаил решительно перехватывает оружие и освобождает девушку. Первая тема стретты излагается в партии Набукко как энергичный призыв к кровавой расправе, а затем проводится у всех солистов, кроме Захарии. Вождь левитов «отвечает» царю новой темой. Ее звучность постепенно нарастает за счет увеличения количества голосов, образуя т. н. форму crescendo, часто используемую Россини именно в стреттах.

Иначе решает Верди финал II акта. После хора левитов, проклинающих Измаила как вероотступника из-за любви к вавилонянке, следует насыщенный событиями раздел tempo d'attacco, в котором попытка Абигайль обманом заполучить корону терпит крах из-за неожиданного появления Набукко. Pezzo concertato передает общее оцепенение от ужаса («Приближаются мгновения рокового гнева»). 12-тактовую тему без изменений поочередно излагают Набукко, Абигайль, Измаил, Фенена, наконец Захария и хор. Такая структура ансамбля, именуемая «ложным каноном», была распространена в итальянских операх начала XIX века, в первую очередь, у Россини. B tempo di mezzo Набукко провозглашает себя богом, однако в тот момент, когда по закону la solita forma должна следовать стретта, порыв ветра срывает с головы царя корону. В оркестре этот эпизод выделен внезапным tutti в динамике ff и долгим нисходящим хроматическим ходом. Завершается финал большим соло поверженного правителя, теряющего рассудок - первый в творчестве Верди пример отказа от стретты. Такая новаторская трактовка привычной финальной структуры станет отличительной чертой финалов поздних опер Верди. 
Таким образом, в «Набукко» композитор продемонстрировал два различных решения большой финальной сцены. В первом финале типичная структура обновлена «изнутри»: зрелостью и разработанностью отличается раздел pezzo concertato, где Верди продемонстрировал умение сочетать в едином ансамбле контрастные характеры и настроения, используя новый для pezzo concertato композиционный принцип цепного соединения тем. При этом в стретте композитор обращается к традиционному россиниевскому crescendo. Bo втором финале, где pezzo concertato, напротив, оказался более консервативным, поскольку композитор применяет старую форму «ложного канона», новаторские устремления Верди проявились самым радикальным образом, «расшатав» саму структуру la solita forma: отныне быстрая стретта перестает быть обязательной нормой. Таким образом, уже в этой ранней опере драматическая правда пересиливает каноны традиции.

\section{Литература:}

1. Дегтярева Н. И. «Аида», «Отелло», «Фальстаф» Дж. Верди: интонационный сюжет и музыкальная драматургия. СПб.: Скифия-принт, 2015.

2. Кенигсберг А. К. Трактовка библейских сюжетов в итальянской опере XIX века // А. К. Кенигсберг. Каприччио: сб. ст. СПб.: СПбГК, 2011. С. 133145.

3. Balthazar S. L. The Primo Ottocento Duet and the Transformation of the Rossinian Code // The Journal of Musicology. Vol. 7. 1989. № 4. P. 471-497.

4. Budden J. The Operas of Verdi: in 3 v. Vol. 1. Rev. ed. New York: Oxford University Press, 1992. $524 \mathrm{p}$

5. Gossett Ph. The «Candeur Virginale» of «Tancredi» // The Musical Times. Vol. 112. 1971. № 1538. P. 326-329.

6. Powers H. S. «La solita forma» and «The Uses of Convention» // Acta Musicologica. Vol. 59. 1987. № 1. P. 65-90. 